\title{
Effect of warming rate on mouse embryos frozen and thawed in glycerol
}

\author{
W. F. Rall* and C. Polge \\ Institute of Animal Physiology, Animal Research Station, 307 Huntingdon Road, \\ Cambridge CB3 OJQ, U.K.
}

\begin{abstract}
Summary. Mouse embryos (8-cell) fully equilibrated in $1.5 \mathrm{M}$-glycerol were cooled slowly $\left(0.5^{\circ} \mathrm{C} / \mathrm{min}\right)$ to temperatures between -7.5 and $-80^{\circ} \mathrm{C}$ before rapid cooling and storage in liquid nitrogen $\left(-196^{\circ} \mathrm{C}\right)$. Some embryos survived rapid warming $\left(\sim 500^{\circ} \mathrm{C} / \mathrm{min}\right)$ irrespective of the temperature at which slow cooling was terminated. However, the highest levels of survival of rapidly warmed embryos were observed when slow cooling was terminated between -25 and $-80^{\circ} \mathrm{C}\left(74-86^{\circ} \%\right)$. In contrast, high survival $\left(75-86^{\circ} \%\right.$ was obtained after slow warming $\left(\sim 2^{\circ} \mathrm{C} / \mathrm{min}\right)$ only when slow cooling was continued to $-55^{\circ} \mathrm{C}$ or below before transfer into liquid $\mathrm{N}_{2}$. Injury to embryos cooled slowly to $-30^{\circ} \mathrm{C}$ and then rapidly to $-196^{\circ} \mathrm{C}$ occurred only when slow warming $\left(\sim 2^{\circ} \mathrm{C} / \mathrm{min}\right)$ was continued to $-60^{\circ} \mathrm{C}$ or above.

Parallel cryomicroscopical observations indicated that embryos became dehydrated during slow cooling to $-30^{\circ} \mathrm{C}$ and did not freeze intracellularly during subsequent rapid cooling $\left(\sim 250^{\circ} \mathrm{C} / \mathrm{min}\right)$ to $-150^{\circ} \mathrm{C}$. During slow warming $\left(2^{\circ} \mathrm{C} / \mathrm{min}\right)$, however, intracellular ice appeared at a temperature between -70 and $-65^{\circ} \mathrm{C}$ and melted when warming was continued to $-30^{\circ} \mathrm{C}$. Intracellular freezing was not observed during rapid warming $\left(250^{\circ} \mathrm{C} / \mathrm{min}\right)$ or during slow warming when slow cooling had been continued to $-65^{\circ} \mathrm{C}$.

These results indicate that glycerol provides superior or equal protection when compared to dimethyl sulphoxide against the deleterious effects of freezing and thawing.
\end{abstract}

\section{Introduction}

Initial success in the cryopreservation of mouse embryos is generally attributed to the presence of molar concentrations of a cryoprotective additive and the use of slow cooling $\left(<1^{\circ} \mathrm{C} / \mathrm{min}\right)$ and warming $\left(<25^{\circ} \mathrm{C} / \mathrm{min}\right.$ ) over the temperature interval $\sim-5$ to $-60^{\circ} \mathrm{C}$ (Whittingham, Leibo \& Mazur, 1972; Wilmut, 1972; Leibo, Mazur \& Jackowski, 1974). Early work on the cryopreservation of sheep and cattle embryos, however, suggested that embryos would survive rapid warming $\left(360^{\circ} \mathrm{C} / \mathrm{min}\right)$ especially when slow cooling $\left(0.3^{\circ} \mathrm{C} / \mathrm{min}\right)$ was terminated at temperatures between -30 and $-45^{\circ} \mathrm{C}$ by direct transfer into liquid nitrogen $\left(-196^{\circ} \mathrm{C}\right)$ (Willadsen, 1977; Willadsen, Polge \& Rowson, 1978; Polge \& Willadsen, 1978). Whittingham, Wood, Farrant, Lee \& Halsey (1979) re-examined the effect of warming rate on the survival of mouse embryos in dimethyl sulphoxide (DMSO) when slow cooling was similarly terminated at various temperatures between -10 and $-80^{\circ} \mathrm{C}$. Their results indicated that high survival could be

* Present address: American Red Cross, Blood Services Laboratories, Cryobiology Laboratory, 9312 Old Georgetown Road, Bethesda, Maryland 20814, U.S.A. 
obtained after rapid warming, but only when slow cooling was terminated between -30 and $-50^{\circ} \mathrm{C}$. On the basis of these findings, Whittingham et al. (1979) suggested that intracellular freezing may play a role in slow-warming injury and perhaps in rapid-warming survival.

There is some evidence that both the type of cryoprotectant and the concentration present during freezing and thawing may modulate the sensitivity of embryos to the rate of warming (Whittingham, 1981). Preliminary data for the mouse (Rall \& Polge, 1981; Kasai, Niwa \& Iritani, 1981 ; Smorag, Katska \& Wierzbowski, 1981) and the cow (Lehn-Jensen \& Greve, 1981; LehnJensen \& Rall, 1983) suggest that embryos frozen in glycerol may exhibit an altered sensitivity to the warming conditions when compared to embryos frozen similarly in DMSO. This paper examines (1) the effect of warming rate on 8-cell mouse embryos equilibrated in glycerol and cooled slowly to temperatures between -7.5 and $-80^{\circ} \mathrm{C}$ before transfer into liquid $\mathrm{N}_{2}$, (2) the critical temperature interval over which injury occurs during slow warming and (3) the microscopical changes in the appearance of embryos in glycerol during cooling and warming.

\section{Materials and Methods}

Source and isolation of embryos. Embryos were obtained from 3- to 8-week-old, random bred MF1 (Ola:MF1) females that were induced to superovulate by intraperitoneal injections of 5 i.u. PMSG and 5 i.u. hCG given $\sim 48 \mathrm{~h}$ apart. Females were paired singly with F1 hybrid (C57BL/CBA $\times$ $\mathrm{CBA} / \mathrm{Ca}$ ) males and inspected the following morning for copulatory plugs. Embryos were flushed from the excised oviducts $\sim 64 \mathrm{~h}$ after the hCG injection with a modified Dulbecco's phosphatebuffered solution (PB1; Whittingham, 1974). After collection, the embryos were washed in fresh PB1, pooled, and held at $\sim 4^{\circ} \mathrm{C}$ until used.

Addition of glycerol, freezing and thawing procedures. Between 15 and 30 embryos were transferred into each of several $10 \times 75 \mathrm{~mm}$ glass test-tubes containing $0 \cdot 1 \mathrm{ml} \mathrm{PB1}$ at room temperature $\left(20-23^{\circ} \mathrm{C}\right.$ ). An equal volume of $\mathrm{PB} 1$ containing $3.0 \mathrm{M}$-glycerol (or in some experiments $3.0 \mathrm{M}$-propylene glycol) was added and mixed (final concentration: $1.5 \mathrm{M}$ ). The resulting embryo suspensions were held at room temperature for $30 \mathrm{~min}$ ( $20 \mathrm{~min}$ for propylene glycol), a time sufficiently long to ensure full equilibration of additive (Rall, Mazur \& McGrath, 1983). Samples were then transferred into the chamber of a programmed liquid $\mathrm{N}_{2}$-vapour freezing machine (model R202, Planner, Sunbury-on-Thames, U.K.) that was precooled to $-7^{\circ} \mathrm{C}$. Ice was induced to form 5 min later by touching the outside of each tube just above the meniscus with forceps precooled in liquid $\mathrm{N}_{2}$. Samples were returned to the chamber and $6 \mathrm{~min}$ later the chamber was cooled at $0.5^{\circ} \mathrm{C} / \mathrm{min}$. Thermocouples in two replicate tubes each containing the suspending solutions continuously monitored the temperature. When the temperature of the replicate tubes had decreased to the appropriate temperature between -7.5 and $-80^{\circ} \mathrm{C}$, samples were removed from the chamber and immediately immersed in liquid $\mathrm{N}_{2}$ (cooling rate: $\sim 500^{\circ} \mathrm{C} / \mathrm{min}$ ) and stored for periods of $18 \mathrm{~h}$ to 60 days. Samples were thawed (1) by transfer into $+37^{\circ} \mathrm{C}$ water with vigorous shaking (warming rate: $\left.\sim 500^{\circ} \mathrm{C} / \mathrm{min}\right) ;(2)$ by transfer into room temperature air $\left(\sim 25^{\circ} / \mathrm{min}\right)$; or (3) by transfer into stirred alcohol $(220 \mathrm{ml}$ in a 1-litre beaker $)$ initially at $\sim-100^{\circ} \mathrm{C}\left(\sim 2^{\circ} \mathrm{C} / \mathrm{min}\right)$. In some experiments samples were removed from the alcohol bath at various subzero temperatures and immediately warmed rapidly in $+37^{\circ} \mathrm{C}$ water.

Dilution of cryoprotectant. After thawing, glycerol was diluted from the samples by the stepwise addition of PB1 at room temperature (Willadsen, 1977). Samples were held at room temperature for $5 \mathrm{~min}$ and then $0.1,0.2,0.2,0.4$ and $0.4 \mathrm{ml} \mathrm{PB} 1$ was added to the tubes and mixed at $10 \mathrm{~min}$ intervals. Embryos in propylene glycol were diluted in 3 steps: $0.1,0.2$ and $0.5 \mathrm{ml} \mathrm{PB1}$ at $5 \mathrm{~min}$ intervals. The contents of each tube were then poured into a Petri dish, the tubes were rinsed with $1 \mathrm{ml} \mathrm{PB1}$, and the embryos collected. Approximately $90 \%$ of the embryos frozen were recovered after dilution.

Survival assay. Embryos were washed in PB1, placed into $20 \mu 1$ drops of BMOC-3 medium 
(Brinster, 1972) in the well of a microtest culture plate (No. 310, Sterilin) under paraffin oil and incubated at $37^{\circ} \mathrm{C}$ in an atmosphere of $5 \% \mathrm{CO}_{2}$ in air. Survival was defined as the percentage of recovered embryos that developed to the expanded blastocyst stage after $48 \mathrm{~h}$.

Cryomicroscopy. Embryos were first placed into PB1 containing glycerol $(1.5 \mathrm{M})$ for $\sim 30 \mathrm{~min}$ at room temperature and then 10 or 11 embryos were transferred into a small drop of the PB1-glycerol solution on a 16-mm diameter No. 1 coverglass and immediately covered with another coverglass (Rall, Reid \& Farrant, 1980). Small slivers of a broken No. 0 coverglass placed around the droplet prevented the embryos from being crushed. Paraffin oil was placed in the remaining airspace between the coverglasses to prevent evaporation and to facilitate recovery of the embryos after cryomicroscopy. The coverglass assembly was then transferred onto the temperature-controlled slide of a cryomicroscope stage (Reid, 1978). The appearance of the embryos during cooling and warming was recorded on time-lapse videotape and $35 \mathrm{~mm}$ Ilford HP5 film using phase-contrast optics on a Wild M20 microscope. To recover the embryos from the coverglass assembly after freezing and thawing, the assembly was transferred into a Petri dish of PB1 containing $1.5 \mathrm{M}$ glycerol, and then the coverglasses were separated using fine-tipped forceps. Finally, the embryos were recovered from the dish and diluted and cultured as above.

\section{Results}

Interaction of the temperature of transfer into liquid $\mathrm{N}_{2}$ and the warming rate

The effect of rapid and slow warming on the survival of embryos cooled slowly to temperatures between -7.5 and $-80^{\circ} \mathrm{C}$ before transfer into liquid $\mathrm{N}_{2}$ is shown in Text-fig. 1. When warmed rapidly $\left(500^{\circ} \mathrm{C} / \mathrm{min}\right)$, some embryos survived transfer from temperatures between -7.5 and $-20^{\circ} \mathrm{C}$ (13-49\%), but survival reached maximum levels when slow cooling was continued to $-25^{\circ} \mathrm{C}$ before transfer $(74 \%)$ and remained high when slow cooling was continued to the lowest temperature

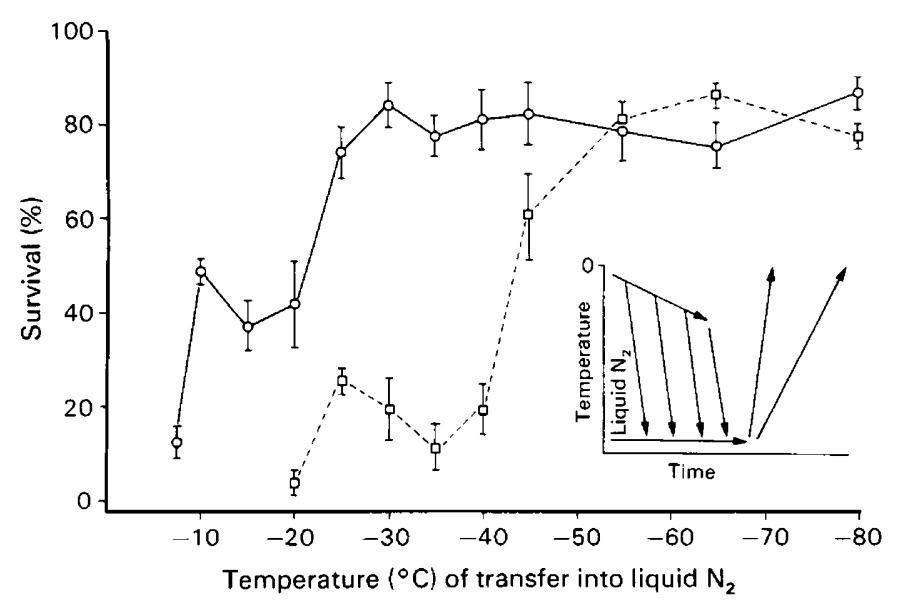

Text-fig. 1. In-vitro survival of 8-cell mouse embryos in $1.5 \mathrm{M}$-glycerol after freezing and thawing. Embryos were cooled slowly $\left(0.5^{\circ} \mathrm{C} / \mathrm{min}\right)$ to various temperatures between -7.5 and $-80^{\circ} \mathrm{C}$ before rapid cooling by immersion in liquid nitrogen $\left(-196^{\circ} \mathrm{C}\right)$ and recovered after slow $\left(\square, \sim 2^{\circ} \mathrm{C} / \mathrm{min}\right.$ ) and rapid $\left(O, \sim 500^{\circ} \mathrm{C} / \mathrm{min}\right)$ warming (see insert diagram). Values are mean \pm s.e.m. The number of replicate tubes and the total number of embryos recovered after thawing (in parentheses) for each curve, starting with: (a) slowly warmed embryos at $-20^{\circ} \mathrm{C}$ were $9(139), 6(113), 7(96), 5(96), 6(114), 8(140), 7(127), 9(131)$ and $8(108)$; and (b) rapidly warmed embryos at $-7 \cdot 5^{\circ} \mathrm{C}$ were $5(86), 6(117), 6(88), 7(100), 6(101), 6(109), 6(105), 8(128)$, 7 (114), 6 (105), 7 (108) and 7 (99). 
examined, $-80^{\circ} \mathrm{C}(76-86 \%)$. With slow warming $\left(2^{\circ} \mathrm{C} / \mathrm{min}\right)$, few embryos survived transfer into liquid $\mathrm{N}_{2}$ after slow cooling to temperatures between -20 and $-40^{\circ} \mathrm{C}(4-25 \%)$, but survival increased to $60 \%$ when slow cooling was continued to $-45^{\circ} \mathrm{C}$ and reached maximum levels (77$86 \%$ ) when slow cooling was terminated between -55 and $-80^{\circ} \mathrm{C}$.

The effect of various rates of warming on the survival of embryos cooled slowly to $-65^{\circ} \mathrm{C}$ and transferred into liquid $\mathrm{N}_{2}$ is summarized in Table 1. Embryos frozen in glycerol or propylene glycol exhibited high survival even though the rate of warming was varied over the range 2 to $500^{\circ} \mathrm{C} / \mathrm{min}$. The survival of embryos frozen in glycerol was not statistically different over this range ( $t$ test analysis). Of the embryos frozen in propylene glycol, only the survivial of those warmed at $800^{\circ} \mathrm{C} / \mathrm{min}$ was statistically lower ( $t$ test, $P=0.03$ ).

Table 1. The effect of warming rate on mouse embryos cooled slowly to $-65^{\circ} \mathrm{C}$ and transferred into liquid nitrogen

\begin{tabular}{lccc}
\hline $\begin{array}{c}\text { Cryoprotective } \\
\text { additive }(1.5 \mathrm{M})\end{array}$ & $\begin{array}{c}\text { Warming rate } \\
\left({ }^{\circ} \mathrm{C} / \mathrm{min}\right)\end{array}$ & $\begin{array}{c}\text { Total no. of } \\
\text { embryos recovered } \\
\text { (replicate samples) }\end{array}$ & $\begin{array}{c}\% \text { Survival } \\
\text { (mean } \pm \text { s.e.m.) }\end{array}$ \\
\hline Glycerol & $\sim 500$ & $108(7)$ & $75 \cdot 4 \pm 4 \cdot 9$ \\
& $\sim 25$ & $137(9)$ & $80 \cdot 6 \pm 4 \cdot 1$ \\
Propylene glycol & $\sim 2$ & $131(9)$ & $86 \cdot 0 \pm 2 \cdot 5$ \\
& $\sim 800$ & $77(5)$ & $69 \cdot 5 \pm 4 \cdot 2$ \\
& $\sim 500$ & $116(5)$ & $83 \cdot 1 \pm 3 \cdot 9$ \\
& $\sim 25$ & $120(6)$ & $70 \cdot 5 \pm 4 \cdot 3$ \\
& $\sim 2$ & $114(6)$ & $73 \cdot 6 \pm 4 \cdot 4$ \\
\hline
\end{tabular}

Temperature interval associated with slow-warming injury

The critical temperature interval which results in slow-warming injury was determined by the procedure shown in the insert diagram of Text-fig. 2. Embryos in glycerol were first cooled slowly to $-30^{\circ} \mathrm{C}$ and then rapidly by transfer into liquid $\mathrm{N}_{2}$. Samples were then warmed slowly $\left(\sim 2^{\circ} \mathrm{C} / \mathrm{min}\right)$

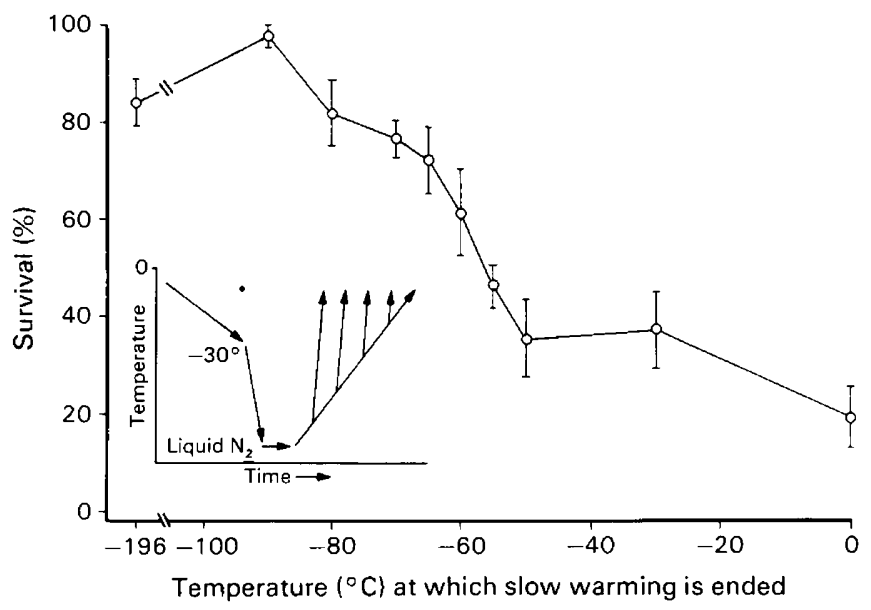

Text-fig. 2. In-vitro survival of 8-cell mouse embryos in $1.5 \mathrm{M}$-glycerol cooled slowly $\left(0.5^{\circ} \mathrm{C} / \mathrm{min}\right)$ to $-30^{\circ} \mathrm{C}$ and then rapidly to $-196^{\circ} \mathrm{C}$ as a function of the temperature at which slow warming $\left(\sim 2^{\circ} \mathrm{C} / \mathrm{min}\right.$ ) was converted to rapid warming (see insert diagram). Values are means \pm s.e.m. The number of replicate tubes and the total number of embryos recovered after thawing (in parentheses) starting at $-196^{\circ} \mathrm{C}$ were $6(109), 3(43), 4(51), 4(62), 4(56), 5(72), 4(61), 6(85), 6$ (87) and 7 (96). 
to various temperatures between -90 and $-30^{\circ} \mathrm{C}$ and then rapidly $\left(\sim 500^{\circ} \mathrm{C} / \mathrm{min}\right)$ to room temperature. The survival of embryos as a function of the temperature at which slow warming was converted to rapid warming is shown in Text-fig. 2. Statistical analysis of these data ( $t$ test) indicated that there was no significant difference between the survival of embryos warmed rapidly from $-196^{\circ} \mathrm{C}$ and those warmed rapidly after slow warming to temperatures between -90 and $-65^{\circ} \mathrm{C}$. However, slow warming to $-60^{\circ} \mathrm{C}$ or above led to significantly lower survivals $(t$ test analysis, $P<0.05$ ), with half the embryos killed by slow warming to $\sim-55^{\circ} \mathrm{C}$.

\section{Cryomicroscopy}

The appearance of 5 embryos during slow cooling $\left(0 \cdot 5^{\circ} \mathrm{C} / \mathrm{min}\right)$ to $-64^{\circ} \mathrm{C}$, rapid cooling to $-152^{\circ} \mathrm{C}$ and subsequent slow warming $\left(\sim 2^{\circ} \mathrm{C} / \mathrm{min}\right)$ is shown in $\mathrm{Pl}$. 1, Figs $1-12$. The first event during slow cooling was the appearance of extracellular ice crystals at $-4^{\circ} \mathrm{C} \mathrm{(Pl.} \mathrm{1,} \mathrm{Fig.} \mathrm{1).} \mathrm{With}$ continued slow cooling, the embryos gradually shrank as the quantity of extracellular ice progressively increased ( $\mathrm{Pl}$. 1, Figs 2-6). When the temperature reached $-64^{\circ} \mathrm{C}$, the embryos were cooled rapidly $\left(\sim 250^{\circ} \mathrm{C} / \mathrm{min}\right)$ to $-152^{\circ} \mathrm{C}(\mathrm{Pl}$. 1, Figs $6 \& 7)$. The appearance of the embryos did not change during rapid cooling, suggesting an absence of visible intracellular freezing. A frequent consequence of such rapid cooling is the formation of a series of dark 'fracture planes' in the iceglassy solution matrix that surrounds the embryos. Occasionally a fracture plane will pass through a zona pellucida and, more rarely, the cytoplasm of an embryo. When the embryos were warmed slowly there was (1) the gradual formation of gas bubbles, usually along the fracture planes, when the temperature was above $-70^{\circ} \mathrm{C}$ (especially above $-40^{\circ} \mathrm{C}$; e.g. Pl. 1, Figs $10 \& 11$ ); (2) the gradual melting of extracellular ice at temperatures above $-60^{\circ} \mathrm{C}$; and (3) the gradual partial rehydration of the embryos (P1. 1, Figs 10-12). After thawing, broken zonae and lysed blastomeres were found in embryos crossed by the fracture plane (Pl. 1, Fig. 12, arrow). Approximately 20 min after Pl. 1, Fig. 12, the embryos were recovered from the cryomicroscope stage, diluted out of glycerol, and then placed into culture. Ten of the 11 embryos frozen $(91 \%)$ developed to the expanded blastocyst stage.

The appearance of 6 embryos during slow cooling to $-31^{\circ} \mathrm{C}$, rapid cooling to $-147^{\circ} \mathrm{C}$ and subsequent slow warming is shown in Pl. 2, Figs 13-28. Extracellular ice crystals appeared at $-4^{\circ} \mathrm{C}$ (Pl. 2, Fig. 13) and grew as the temperature was reduced to $-31^{\circ} \mathrm{C}$. The embryos became partly obscured by the ice and gradually dehydrated (Pl. 2, Figs 14-16). When the temperature reached $-31^{\circ} \mathrm{C}$, the embryos were cooled rapidly $\left(\sim 250^{\circ} \mathrm{C} / \mathrm{min}\right)$ to $-147^{\circ} \mathrm{C}(\mathrm{Pl}$. 2, Figs $16 \& 17)$. The absence of changes in the appearance of the embryos or the residual extracellular liquid during rapid cooling suggests that no additional ice formed. During slow warming, the embryos exhibited a slight increase in opacity at $\sim-70^{\circ} \mathrm{C}$ (Pl. 2, Fig. 19). Continued slow warming led to a complex series of changes in the appearance of the embryos and their surroundings. These changes included: (1) the gradual growth $\left(\sim-70\right.$ to $-50^{\circ} \mathrm{C} ; \mathrm{Pl}$. 2, Figs $\left.20-22\right)$ and dissolution $(\sim-50$ to $-30^{\circ} \mathrm{C} ; \mathrm{Pl}$. 2, Figs 22-26) of a dark crystalline material (presumably ice) outside the zona pellucida and within the perivitelline space; (2) a second darkening of the cytoplasm at $\sim-50^{\circ} \mathrm{C}(\mathrm{Pl}$. 2 , Fig. $22)$; (3) the gradual disappearance of the dark intracellular material as the temperature reached $-30^{\circ} \mathrm{C}$ (Pl. 2, Fig. 26); and (4) the gradual formation and dissolution of gas bubbles at temperatures above $\sim-70$ and $-15^{\circ} \mathrm{C}$, respectively. Approximately $10 \mathrm{~min}$ after Pl. 2, Fig. 28, the embryos were recovered from the cryomicroscope stage, diluted out of the glycerol, and placed into culture. Two of the 11 embryos frozen $(18 \%)$ developed to the expanded blastocyst stage even though each embryo exhibited all of the blackening events.

\section{Discussion}

The ability of glycerol $(1.5 \mathrm{M})$ to protect mouse embryos from the deleterious effects of freezing and thawing depended on the cooling and warming conditions. Embryos exhibited high survival (77- 
$\left.86^{\circ}\right)$ after slow warming $\left(2^{\circ} \mathrm{C} / \mathrm{min}\right)$ when slow cooling $\left(0.5^{\circ} \mathrm{C} / \mathrm{min}\right)$ was terminated at any temperature between -55 and $-80^{\circ} \mathrm{C}$ by rapid cooling $\left(500^{\circ} \mathrm{C} / \mathrm{min}\right)$ in liquid $\mathrm{N}_{2}$. Equally high survival was obtained after rapid warming $\left(500^{\circ} \mathrm{C} / \mathrm{min}\right)$ when slow cooling was terminated at temperatures between -25 and $-80^{\circ} \mathrm{C}$ before rapid cooling in liquid $\mathrm{N}_{2}$. Therefore, in contrast to earlier findings for embryos frozen in DMSO (Whittingham et al., 1972, 1979; Wilmut, 1972), our results indicate that embryos in glycerol (or propylene glycol) become insensitive to the rate of warming when slow cooling is continued below $-50^{\circ} \mathrm{C}$. These findings confirm and expand earlier observations on the survival of slowly frozen mouse embryos in glycerol or ethylene glycol after rapid and slow warming (Rall \& Polge, 1981; Kasai et al., 1981; Miyamoto \& Ishibashi, 1983). Injury associated with rapid warming has been attributed to osmotic stresses that may occur at subzero temperatures (Leibo et al., 1974). Two factors may permit embryos in $1.5 \mathrm{M}$-glycerol (or propylene glycol) to avoid rapid-warming injury. Firstly, the concentration of additive present during cryopreservation may influence the osmotic behaviour of the embryos during thawing. Whittingham (1981) has observed a decrease in the sensitivity of slowly frozen mouse embryos to the rate of warming when the concentration of DMSO is increased from 1.0 to $2.0 \mathrm{M}$ and similar results have been reported for sheep embryos (Willadsen, 1977). Secondly, the extent of intracellular equilibrium of the additive before cryopreservation may also play an important role in rapid warming injury. Cryoprotectants are usually added to mouse embryos at $0^{\circ} \mathrm{C}$, conditions that ensure little or no penetration of the additive (Leibo et al., 1974; Jackowski, Leibo \& Mazur, 1980). Although the extent of prior permeation of DMSO does not influence the survival of slowly warmed embryos (Leibo et al., 1974), full permeation of glycerol may modify or eliminate the osmotic stresses that presumably occur during rapid warming. For example, McGann (1979) has reported that the extent of glycerol permeation determines whether slowly frozen mammalian tissue-culture cells survive rapid warming.

Our cryomicroscopical observations of embryos during slow cooling to $-64^{\circ} \mathrm{C}$, rapid cooling to $-150^{\circ} \mathrm{C}$ and subsequent slow warming (Plate 1) confirm the widely held view of events during cryopreservation (Whittingham et al., 1972; Leibo, McGrath \& Cravalho, 1978). These events include: (1) the gradual shrinkage of embryos during slow cooling as the extracellular solution progressively freezes; (2) the absence of visible crystallization of the concentrated cytoplasm and residual extracellular liquid during subsequent rapid cooling; (3) the gradual melting of extracellular ice and partial rehydration of the embryos during slow warming; and (4) the gradual swelling of the embryos to their initial volume after the ice melts. Two additional observations warrant further consideration. Firstly, a series of interconnecting 'fracture-planes' formed in the extracellular ice matrix during rapid cooling. When a fracture plane passed through an embryo, cracked or broken zonae were found after thawing (Plates 1 and 2, arrows). Fracture planes may, therefore, explain the origin of zona damage frequently observed after the cryopreservation of mammalian embryos (Willadsen, Polge, Rowson \& Moor, 1976; Whittingham \& Adams, 1976). The fracturing presumably results from mechanical stresses caused by a temperature gradient within the ice crystals (Gold, 1961, 1963) or by differences in the thermal expansion of adjacent materials (e.g. the ice crystals, glassy solid and perhaps the container walls; Mantovani \& Valeri,

\section{PLATE 1}

Microscopical appearance of five 8-cell mouse embryos equilibrated in $1.5 \mathrm{M}$-glycerol during slow cooling and warming. The embryos were cooled slowly $\left(0.5^{\circ} \mathrm{C} / \mathrm{min}\right)$ to $-64^{\circ} \mathrm{C}$ and the photographs in Figs 1-6 were taken at the indicated temperatures. Fig. 1 shows the extracellular ice front as it passes the embryos. The embryos were then cooled rapidly $\left(\sim 250^{\circ} \mathrm{C} / \mathrm{min}\right.$ ) to $-152^{\circ} \mathrm{C}$ (Fig. 7). Subsequently the embryos were warmed rapidly to $-100^{\circ} \mathrm{C}$ and then slowly $\left(5^{\circ} \mathrm{C} / \mathrm{min}\right)$ to room temperature (Figs 8-12). The scale bar represents approximately $50 \mu \mathrm{m}$. See text for details. 
PLATE 1
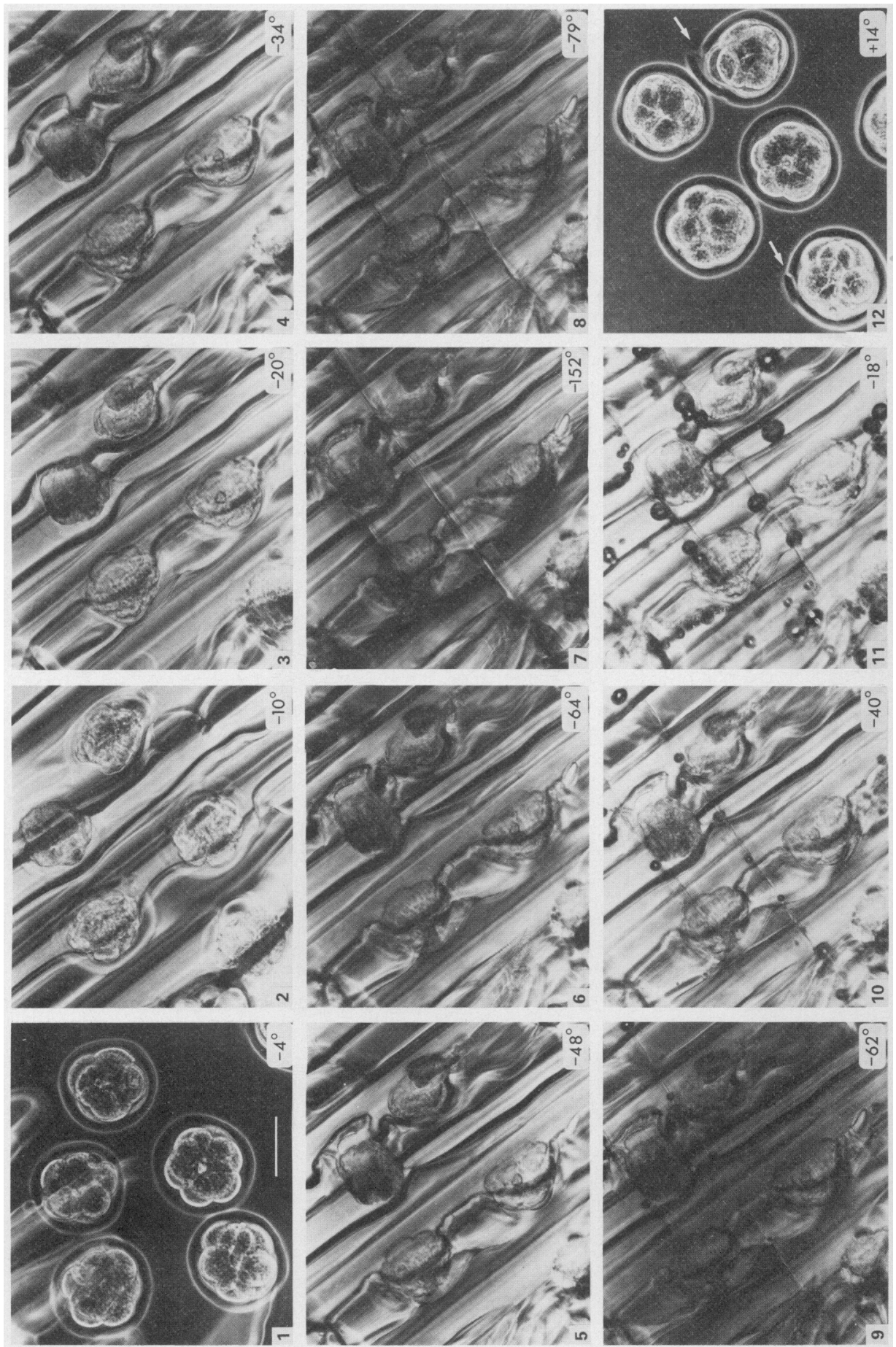
PLATF 2
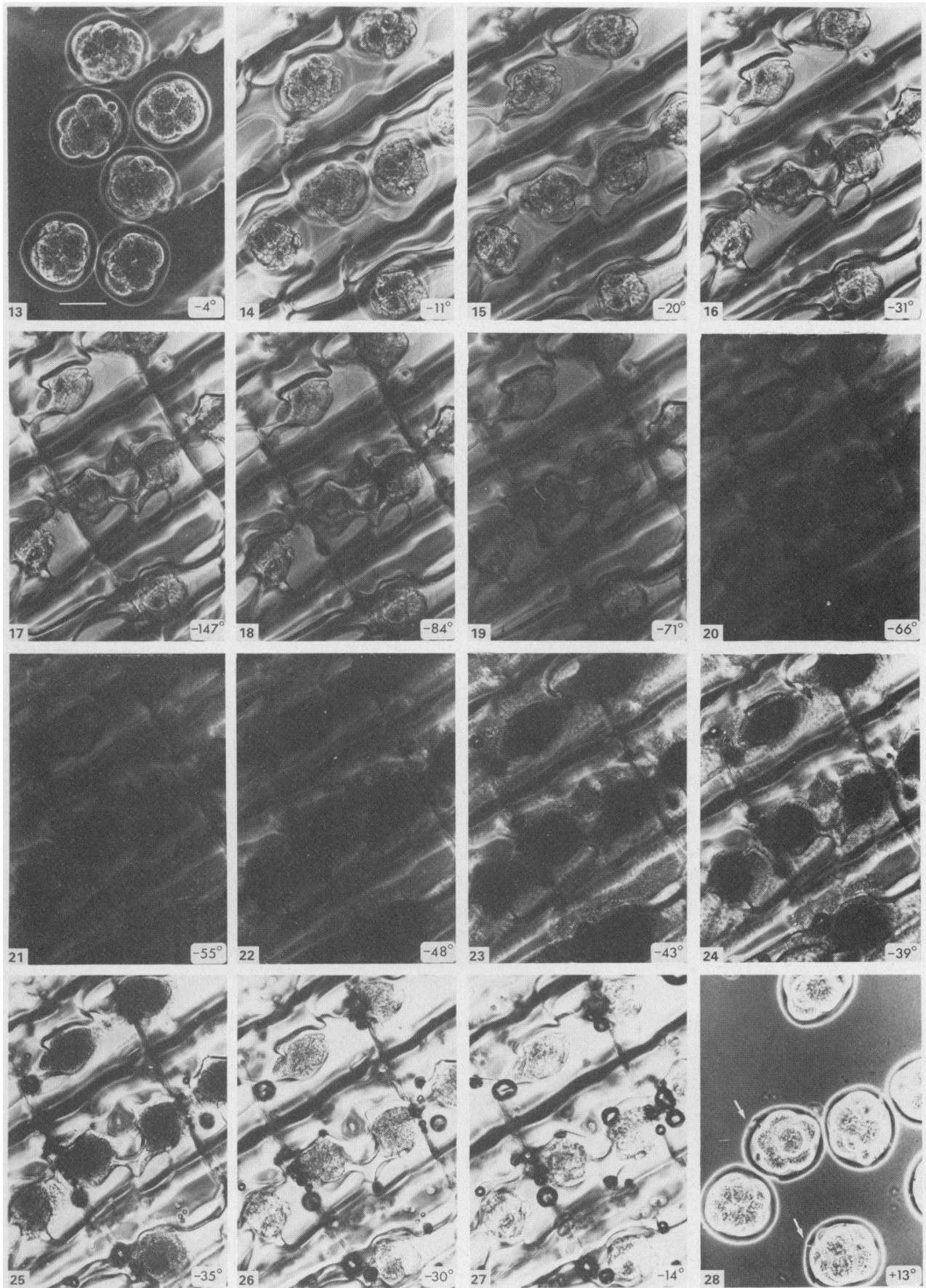
1978). Secondly, gas bubbles formed during slow warming, usually when the temperature was above $-70^{\circ} \mathrm{C}$ (see Plate 1). Bubbles generally nucleated along the fracture planes and often detached and floated in the liquid-filled channels between the ice crystals. Although gas bubbles are thought to disrupt cells during freezing and thawing (Scholander, Flagg, Hock \& Irving, 1953; Billingham, 1957; Steponkus \& Dowgert, 1981), embryos recovered from the cryomicroscope stage after slow freezing and thawing exhibited high in-vitro survival.

The survival of embryos in glycerol after slow cooling to temperatures between -25 and $-45^{\circ} \mathrm{C}$ and subsequent rapid cooling to $-196^{\circ} \mathrm{C}$ depended on the warming conditions in that survival was high after rapid warming but low after slow warming (see Text-fig. 1). These results agree with earlier observations on the survival of similarly cooled mouse (Whittingham et al., 1979) and sheep (Willadsen, 1977) embryos in DMSO and cattle embryos in glycerol (Lehn-Jensen, Greve \& PerezNavas, 1981). The present survival data suggest that slow-warming injury of embryos in glycerol results from a mechanism similar to that found for embryos in DMSO (Rall et al., 1980; Rall, Reid \& Polge, 1984). According to this view, slow cooling to temperatures between -25 and $-45^{\circ} \mathrm{C}$ yields a concentrated residual extracellular liquid and dehydrated cytoplasm that will supercool and form a metastable glass on subsequent rapid cooling. Slow warming permits sufficient time for the devitrification (crystallization) of the glassy cytoplasm and extracellular liquid and leads to low survival. Rapid warming does not allow time for devitrification and leads to high rates of survival. Cryomicroscopy of embryos frozen in glycerol by this procedure confirms this interpretation (Plate 2). A gradual dehydration of the cytoplasm and increase in the amount of extracellular ice was observed during slow cooling to $-30^{\circ} \mathrm{C}$ and, during subsequent rapid cooling to $-147^{\circ} \mathrm{C}$, no additional crystallization occurred. During slow warming, a gradual blackening was observed $\left(\sim-70\right.$ to $\left.-55^{\circ} \mathrm{C}\right)$ that is characteristic of the devitrification of the cytoplasm and extracellular glass. However, if similarly cooled embryos are warmed rapidly $\left(\sim 250^{\circ} \mathrm{C} / \mathrm{min}\right)$, none of the darkening events are observed and the embryos exhibit high in-vitro survival (W. F. Rall, unpublished observations). Parallel studies indicate that injury occurs only when slow warming is continued to $-60^{\circ} \mathrm{C}$ or above (Text-fig. 2).

Embryos frozen in glycerol have a superior or equal rate of survival after thawing when compared to embryos treated similarly in DMSO. Furthermore, comparison of the data in Text-fig. 2 with the survival results for embryos frozen and thawed similarly in DMSO (Rall et al., 1980) indicates that embryos in glycerol tolerate slow warming to temperatures some $10^{\circ} \mathrm{C}$ higher. The improved survival presumably results from the superior glass-forming abilities of glycerol solutions (Cocks, Hildenbrandt \& Shepard, 1975). This property results from the facts that (1) glycerol solutions generally exhibit a higher viscosity than the equivalent DMSO solutions, and (2) glycerol is less effective than DMSO in reducing the quantity of ice formed at any subzero temperature (Shepard, Goldston \& Cocks, 1976). Therefore, after slow cooling to the same subzero temperature, embryos frozen in glycerol are more likely to form a metastable glass and avoid the potentially deleterious effects associated with the formation of intracellular ice.

W.F.R. was supported by a Fellowship from the Stanley Thomas Johnson Foundation.

\section{PLATE 2}

Microscopical appearance of six 8-cell mouse embryos equilibrated in $1.5 \mathrm{M}$-glycerol during interrupted slow cooling and slow warming. The embryos were cooled slowly $\left(0.5^{\circ} \mathrm{C} / \mathrm{min}\right)$ to $-31^{\circ} \mathrm{C}$ and the photographs in Figs $13-16$ were taken at the indicated temperatures. The embryos were then cooled rapidly $\left(\sim 250^{\circ} \mathrm{C} / \mathrm{min}\right)$ to $-147^{\circ} \mathrm{C}$ (Fig. 17). Subsequently the embryos were warmed rapidly to $-100^{\circ} \mathrm{C}$ and then siowly $\left(2.5^{\circ} \mathrm{C} / \mathrm{min}\right)$ to room temperature (Figs 18-28). The scale bar represents approximately $50 \mu \mathrm{m}$. See text for details. 


\section{References}

Billingham, R.E. (1957) Bubbles in thawed cornea. Proc. R. Soc. $B$ 147, 530-531.

Brinster, R.L. (1972) Cultivation of the mammalian embryo. In Growth Nutrition, and Metabolism of Cells in Culture, Vol. II, pp. 251-286. Eds G. H. Rothblat \& V. J. Cristofalo. Academic Press, New York.

Cocks, F.H., Hildebrandt, W.H. \& Shepard, M.L. (1975) Comparison of the low-temperature crystallization of glasses in the ternary systems $\mathrm{H}_{2} \mathrm{O}-\mathrm{NaCl}$-dimethyl sulfoxide and $\mathrm{H}_{2} \mathrm{O}-\mathrm{NaCl}$-glycerol. J. appl. Physics 46, 3444-3448.

Gold, L.W. (1961) Formation of cracks in ice plates by thermal shock. Nature, Lond. 192, 130-131.

Gold, L.W. (1963) Crack formation in ice plates by thermal shock. Can. J. Physics 41, 1712-1728.

Jackowski, S.C., Leibo, S.P. \& Mazur, P. (1980) Glycerol permeabilities of fertilized and unfertilized mouse ova. J. exp. Zool. 212, 329-341.

Kasai, M., Niwa, K. \& Iritani, A. (1981) Effects of various cryoprotectants on the survival of unfrozen and frozen mouse embryos. J. Reprod. Fert. 63, 175-180.

Lehn-Jensen, H. \& Greve, T. (1981) Survival of cow blastocysts utilizing short freezing curves. Nord. VetMed. 33, 523-529.

Lehn-Jensen, H. \& Rall, W.F. (1983) Cryomicroscopic observations of cattle embryos during freezing and thawing. Theriogenology 19, 263-277.

Lehn-Jensen, H., Greve, T. \& Perez-Navas, A. (1981) Two step freezing of cow embryos in $1.4 \mathrm{M}$-glycerol. Theriogenology 15, 427-432.

Leibo, S.P., Mazur, P. \& Jackowski, S.C. (1974) Factors affecting survival of mouse embryos during freezing and thawing. Expl Cell Res. 89, 79-88.

Leibo, S.P., McGrath, J.J. \& Cravalho, E.G. (1978) Microscopic observation of intracellular ice formation in unfertilized mouse ova as a function of cooling rate. Cryobiology 15, 257-271.

Mantovani, S. \& Valeri, S. (1978) Mechanical behaviour at ice-metal interfaces. Phil. Mag. A 37, 17-26.

McGann, L.E. (1979) Optimal temperature ranges for control of cooling rate. Cryobiology 16, 211-216.

Miyamoto, H. \& Ishibashi, T. (1983) Solid $\mathrm{CO}_{2}$ freezing of mouse embryos. J. Reprod. Fert. 67, 107-111.

Polge, C. \& Willadsen, S.M. (1978) Freezing eggs and embryos of farm animals. Cryobiology 15, 370-373.

Rall, W.F. \& Polge, C. (1981) Rapid- and slow-warming survival of mouse embryos in glycerol. Cryobiology 18, 619 Abstr.

Rall, W.F., Reid, D.S. \& Farrant, J. (1980) Innocuous biological freezing during warming. Nature, Lond. 286, $511-514$.

Rall, W.F., Mazur, P. \& McGrath, J.J. (1983) Depression of the ice-nucleation temperature of rapidly cooled mouse embryos by glycerol and dimethyl sulfoxide. Biophys. J. 41, 1-12.

Rall, W.F., Reid, D.S. \& Polge, C. (1984) Analysis of slow-warming injury of mouse embryos by cryomicroscopical and physio-chemical methods. Cryobiology 21, (in press).

Reid, D.S. (1978) A programmed controlled temperature microscope stage. J. Microscopy 114, 241-248.

Scholander, P.F., Flagg, W., Hock, R.J. \& Irving, L. (1953) Studies on the physiology of frozen plants and animals in the arctic. J. cell. comp. Physiol. 42, Suppl. 1, $1-56$.

Shepard, M.L., Goldston, C.S. \& Cocks, F.H. (1976) The $\mathrm{H}_{2} \mathrm{O}-\mathrm{NaCl}$-glycerol phase diagram and its application in cryobiology. Cryobiology 13, 9-23.

Smorag, Z., Katska, L. \& Wierzbowski, S. (1981) Some factors affecting the success of embryo-freezing: storage before freezing, superovulation rate, PBS concentration, cooling and thawing rates. In Frozen Storage of Laboratory Animals, pp. 45-53. Ed. G. H. Zeilmaker. Gustav Fischer Verlag, Stuttgart.

Steponkus, P.L. \& Dowgert, M.F. (1981) Gas bubble formation during intracellular ice formation. CryoLetters 2, 42-47.

Whittingham, D.G. (1974) Embryo banks in the future of developmental genetics. Genetics, Princeton 78, 395402.

Whittingham, D.G. (1981) Sensitivity of mouse embryos to the rate of thawing. In Frozen Storage of Laboratory Animals, pp. 21-32. Ed. G. H. Zeilmaker. Gustav Fischer Verlag, Stuttgart.

Whittingham, D.G. \& Adams, C.E. (1976) Low temperature preservation of rabbit embryos. J. Reprod. Fert. 47, 269-274.

Whittingham, D.G., Leibo, S.P. \& Mazur, P. (1972) Survival of mouse embryos frozen to $-196^{\circ} \mathrm{C}$ and $-269^{\circ}$ C. Science, N.Y. 178, 411-414.

Whittingham, D.G., Wood, M.J., Farrant, J., Lee, H. \& Halsey, J.A. (1979) Survival of frozen mouse embryos after rapid thawing from $-196^{\circ} \mathrm{C}$. J. Reprod. Fert. 56, 11-21.

Willadsen, S.M. (1977) Factors affecting the survival of sheep embryos during deep-freezing and thawing. In The Freezing of Mammalian Embryos (Ciba Fdn Symp. No. 52), pp. 175-189. Eds K. Elliot \& J. Whelan. Elsevier/North Holland, Amsterdam.

Willadsen, S.M., Polge, C., Rowson, L.E.A. \& Moor, R.M. (1976) Deep freezing of sheep embryos. $J$. Reprod. Fert. 46, 151-154.

Willadsen, S.M., Polge, C. \& Rowson, L.E.A. (1978) In vitro storage of cattle embryos. In Control of Reproduction in the Cow, Vol. 1, pp. 427-436. Ed. J. Sreenan. European Economic Community, Luxembourg.

Wilmut, I. (1972) The effect of cooling rate, warming rate, cryoprotective agent, and stage of development on survival of mouse embryos during freezing and thawing. Life Sci. 11, 1071-1079.

Received 13 June 1983 